Faculté de Droit et des Sciences Economiques de Paris: Laboratoire d'Anthropologie Juridique

LE Laboratoire d'Anthropologie Juridique entreprend l'inventaire, par populations, des termes africains utilisés dans tous les domaines où le Droit est concerné; il s'agit essentiellement d'analyser les termes et leurs diverses significations, en s'efforçant d'éviter toute référence explicite ou implicite aux catégories occidentales, et de décrire, avec précision et concision, les réalités qu'ils recouvrent. A côté du sens proprement juridique de chaque terme, il sera fait mention de toutes ses connotations sociologiques, politiques, économiques, religieuses; en outre, on prendra soin de suivre l'évolution des mots et des faits qui s'y rapportent, durant la colonisation et depuis l'indépendance, en précisant leurs facultés de résistance et d'adaptation.

La constitution de ce fichier requiert le concours des juristes, anthropologues, linguistes et sociologues; dans toute la mesure du possible un ou plusieurs chercheurs africains sont invités à participer à l'élaboration du dictionnaire relatif au droit de leur population. Le Laboratoire établit des fiches à partir d'ouvrages et articles publiés et des exposés faits par les collaborateurs au cours des séances de travail hebdomadaires et des séminaires semestriels qu'il organise. Les autres fiches sont rédigées directement par les chercheurs qui apportent leur concours au Dictionnaire. L'entreprise étant collective, le fichier central est à la disposition de tous les participants; chaque année, une liste des fiches établies sera dressée et chacun, s'il en manifeste le désir, recevra les fiches relatives aux langues et ethnies auxquelles il s'intéresse particulièrement. Toutefois, aucun renseignement inédit ne pourra être utilisé sans l'autorisation de l'auteur.

Pour chaque langue et ethnie, les fiches seront classées selon les rubriques suivantes: I - La pensée juridique (a) formes et fondemențs du droit, (b) représentations et classifications, $(c)$ violations et restaurations, (d) procédures et modes de preuves; II - Droit et société $(e)$ le pouvoir, $(f)$ groupes de parenté et localité, $(g)$ groupes d'activité; III - Droit et personne $(h)$ signes de la personne, $(i)$ parenté et alliance, $(j)$ mariage, $(k)$ succession; IV - Droit et richesses $(l)$ facteurs de production, $(m)$ produits.

Le Laboratoire remercie tous ceux qui voudront bien contribuer à la réussite de ce travail d'équipe par l'envoi de fiches ou de tirés à part de leurs articles ou par leur participation aux séminaires.

(Contribution de M. Raymond Verdier, Chef du Laboratoire d'Anthropologie Juridique, I 3 rue Roger Verlomme, Paris III $)$ )

\title{
Bantu Grammar Programme, Royal Museum of Central Africa, Tervuren
}

Work currently in progress in the linguistics department for the 'Lolemi' Bantu grammar programme includes the following: ( $\mathrm{I}$ ) maintaining the card index by incorporating new material; (2) comparative grammar studies: adjective, object-infix, imperative, ' all, alone '; (3) studies of individual languages: (a) with informants: Binja, Mbala (for these two the data-collecting stage is over), Shi, Tsio, Yanzi; (b) from published texts: Mabale. This work is carried out by three research workers (at present, L. Lubanda, L. Polak, M. Servranckx) and by Professor A. E. Meeussen, who directs the team.

Lolemi publications: in Africana Linguistica II (Annals of the Museum, Human Sciences, 55, 1965): Bynon-Polak (ordinals), Stappers (other numerals), Doneux (bibliography); in the press: in Africana Linguistica III: Doneux (class 15), Kadima ("other '), Meeussen (grammatical reconstructions), Sebasoni (prefinal), Stappers (passive). A copy of the indexed information will be sent on request to anybody interested in working by correspondence on subjects relevant to the project. 
In connexion with Lolemi, Professor W. J. Samarin (now in Leiden, Holland) has undertaken a study of ideophones in Bantu, as part of a more general study of ideophones in African languages. Persons interested in acquiring a copy of a ten-sentence questionnaire for a comparative study of ideophones should write to Professor Samarin at the AfrikaStudiecentrum, Stationsplein ro, Leiden.

\section{Committee on African Studies, University of Washington, Seattle}

AN interdepartmental undergraduate and graduate program in African studies is now being developed at the University of Washington. Its major orientation is initially in anthropology and sociology but the program expects to develop training in political science and linguistics as well as in other areas. No degree is offered in African studies; regular work is taken through the departments, but the student has the opportunity to develop an African speciality. The program covers Africa South of the Sahara as a whole. The teachers include: Professor Simon Ottenberg (Anthropology, West Africa, social change, political anthropology); Professor Edgar Winans (Anthropology, East Africa, ecology, social change, political anthropology and law); Professor Peter Wilson (Madagascar, cultural anthropology, ethnohistory); Professor Pierre van den Berghe (Sociology, Southern Africa, social stratification, race relations, social change); Professor James Crutchfield (Economics, fishing resources); Professor Jon Bridgman (History, German African History); Professor John Williams (History, South Africa), Mr. William Nash (Library). For further information on the program write to Professor Simon Ottenberg, Department of Anthropology, University of Washington, Seattle, Washington 98105 , U.S.A.

\section{African Studies in Poland I}

OvEr the last ten years political changes in Africa have made it a focus of scientific interest in Poland. In 1956 the Polish Ethnological Society organized its first post-war seminar on African problems (Wroctaw, 9-I I May). The quarterly Kultura i Spoleczeristwo, started in 1957 by the Research Centre for Sociology and History of Culture of the Polish Academy of Sciences, has brought Africa into the wider sphere of research on contemporary culture. This periodical, connected with sociologists at the University of Lódz, was the first to present African problems from the contemporary as well as the ethnographic viewpoint. Until the mid-nineteen-fifties the interests of Polish scholars did not extend beyond Arabic Africa and Ethiopia. In Polish periodicals a peak of interest in African problems was reached in 1961 .

In 1960 a Department for African and Asian countries was established in the Polish Intitute of International Affairs and in 1964 the Department of African Countries was formed, under the Directorship of Dr. Jerzy Procopczuk, to deal with African political, economic, and social problems. At the University of Warsaw research on African problems is co-ordinated in the Centre for African Studies founded in May 1962 and headed by Professor Stefan Strelcyn. The centre runs post-graduate courses and co-operates with specialists at other centres for 'inter-disciplinary' seminars. Results of research are published in the bulletin Africana in English and French.

The Chair of Semitic Philology in the Institute for Oriental Studies is concerned with the languages and culture of Ethiopia, but research in Arabic is also conducted. Research on the Egyptian and Coptic languages is through the Chair of the Philology of the Ancient East. Practical study of Hausa, Swahili, Amharic, and Bambara is also available. Professor Kazimierz Michatowski, holder of the Warsaw University Chair in Mediterranean

1 See also Africa, xxxii. 2, 1962, p. 173; xxxv. 1, 1965, p. 101; xxxvi. I, 1966, pp. 86-87. 